\title{
Pemanfaatan Buku Teks Elektronik di Perpustakaan Fakultas Ekonomika dan Bisnis Universitas Gadjah Mada
}

\author{
Maryatun $^{1^{*}}$ \\ ${ }^{1}$ Perpustakaan Fakultas Ekonomika dan Bisnis, Universitas Gadjah Mada \\ *Korespondensi: maryatun@ugm.ac.id
}

\begin{abstract}
The development of technology and information has brough an impact with provision of electronic textbooks. This study aims to explore the use of electronic textbooks at the Faculty of Economics and Business, Gadjah Mada University. The sample of the study consists of 100 people that were recruited through purposive sampling technique. The informant criterias were undergraduate students who have used electronic textbooks and were still registered as a student. The results showed that the electronic textbooks have been used by students even though it was not optimal due to the collection provision transitionfrom the textbooks to the electronic textbooks. Most of students use the electronic textbooks for lecture purposes, they use laptop for accessing the ebooks. It can be seen from the data that most students need training on how to take notes, highlighting, and sharing the ebooks with friends. However, some students still prefer printed textbooks than the electronic textbooks. The use of electronic textbooks for students can be seen as positive experience for their learning activities. The majority of students agreed if the electronic textbooks are to be subscribed to by the library. Students reccommended the library to provide information services especially about how to best use the ebooks, conducting socialization through social media, rewarding students who actively use the electronic textbooks, and named one of the outstanding students as an ebooks ambassador.
\end{abstract}

Keywords: electronic textbook; ebooks; ebook services; university library

\begin{abstract}
Abstrak
Berkembangnya teknologi dan informasi memberi dampak terhadap layanan informasi perpustakaan salah satunya trend penyediaan buku teks elektronik. Penelitian ini bertujuan untuk mengetahui pemanfaatan buku teks elektronik di Fakultas Ekonomika dan Bisnis Universitas Gadjah Mada. Sampel penelitian berjumlah 100 orang dengan teknik pengambilan sampel secara purposive. Kriteria sampel adalah mahasiswa S1 yang pernah menggunakan buku teks elektronik dan masih berstatus aktif sebagai mahasiswa. Hasil penelitian menunjukkan bahwa pemanfaatan buku teks elektronik yang dilanggan telah dimanfaatkan oleh mahasiswa meskipun belum optimal disebabkan karena penggunaan buku teks elektronik masih dalam masa transisi dari buku teks cetak ke buku teks elektronik yang baru dilanggan selama satu semester. Sebagian besar mahasiswa menggunakan buku teks elektronik untuk kuliah. Buku teks diakses melalui laptop, dan sebagian besar mahasiswa masih memerlukan petunjuk cara membuat catatan, highlight, dan berbagi dengan teman. Namun demikian, sebagian besar mahasiswa masih merasa lebih nyaman membaca buku teks cetak dari pada buku teks elektronik. Pemanfaatan buku teks elektronik bagi mahasiswa merupakan pengalaman positif dalam kegiatan belajar dan mahasiswa setuju apabila buku teks elektronik untuk tetap dilanggan oleh fakultas. Beberapa upaya yang perlu dilakukan oleh perpustakaan untuk meningkatkan pemanfaatan buku teks elektronik antara lain, memberikan layanan bimbingan pemanfaatan secara berkala, melakukan sosialisasi melalui media sosial, memberikan reward kepada pengguna aktif, serta menobatkan salah satu mahasiswa berprestasi sebagai duta baca sumber materi elektronik. Hasil penelitian ini bermanfaat bagi perpustakaan lain yang sedang mengembangkan koleksi buku teks elektronik maupun koleksi digital lain bagi pemustakanya.
\end{abstract}

Kata kunci: buku teks elektronik; buku elektronik; pemanfaatan buku teks; perpustakaan perguruan tinggi

\section{PENDAHULUAN}

Ketersediaan sumber belajar yang memadai di perpustakaan perguruan tinggi diharapkan dapat mendukung proses belajar mengajar. Salah satu sumber belajar berupa buku teks mata kuliah. Tersedianya buku teks dengan kuantitas dan kualitas yang sesuai kebutuhan pemustaka akan membantu kelancaran proses pembelajaran. 
Terbatasnya anggaran pengadaan buku teks di perpustakaan menyebabkan secara kuantitas tidak dapat memenuhi kebutuhan buku teks mata kuliah kepada seluruh mahasiswa, sedangkan secara kualitas buku teks yang asli harganya jauh lebih mahal dibandingkan buku bajakan yang kualitasnya hampir sama dengan buku dari penerbit aslinya. Berkembangnya teknologi saat ini memungkinkan perpustakaan dapat membeli buku teks dengan harga lebih murah dengan tersedianya buku teks dalam bentuk buku elektronik. Namun, hal tersebut belum banyak dilakukan oleh perpustakaan. Selain itu masih sedikitnya buku teks mata kuliah yang diterbitkan dalam bentuk buku elektronik. Kouis \& Konstantinou (2014) dalam penelitiannya menyebutkan bahwa dengan kemajuan teknologi buku elektronik akan menggantikan buku cetak tetapi tidak akan terjadi dalam waktu dekat. Buku cetak masih menjadi rujukan utama setiap mata kuliah meskipun saat ini sudah tersedia jenis buku elektronik (Kouis \& Konstantinou, 2014; Woody, Daniel, \& Baker, 2010).

Oleh karena itu, saat ini keberadaan buku teks dalam format cetak masih diperlukan sebagai sumber belajar sivitas akademika. Prastowo (2015) menyampaikan bahwa buku teks adalah buku yang berisi ilmu pengetahuan, yang diturunkan dari kompetensi dasar yang tertuang dalam kurikulum, di mana buku tersebut digunakan oleh peserta didik untuk belajar. Menyusun buku teks bukan merupakan hal yang mudah karena penulis buku teks harus memahami berbagai gaya belajar individu (Muslich, 2016)

Ketersediaan buku teks di perpustakaan Fakultas Ekonomika dan Bisnis Universitas Gadjah Mada (FEB UGM) dapat dinilai belum cukup memadai dalam mendukung kegiatan perkuliahan. Rata-rata jumlah buku teks sebagai buku wajib mata kuliah tersedia tiga sampai dua puluh eksemplar yang mengakibatkan sering terjadi antrian pemesanan dalam peminjaman buku. Sebagian besar silabi mata kuliah di FEB UGM menggunakan sumber bacaan wajib dari buku teks berbahasa Inggris, dalam hal ini buku cetak impor. Perpustakaan berupaya mengoptimalkan penggunaan anggaran pengadaan buku dengan pembelian buku cetak impor dari penerbit melalui distributor yang ada di berbagai kota untuk mendapatkan buku dengan kualitas yang baik. Namun secara kuantitas perpustakaan hanya mampu membeli dalam jumlah terbatas. Format buku dalam bentuk elektronik disediakan oleh perpustakaan dalam upaya untuk menyesuaikan permintaan dan harapan pemustaka dari generasi muda dari mahasiswa, peneliti, dan anggota fakultas yang lebih suka mengakses informasi dalam format elektronik (Rao, 2018). Berbagai penelitian tentang buku elektronik, mendefinisikan bahwa buku elektronik adalah sebagai teks dalam format digital dan diakses melalui layar elektronik (Rockinson-Szapkiw et.al, 2013).

Pada awal semester ganjil tahun ajaran 2018/2019 perpustakaan mendapatkan penawaran pengadaan buku teks elektronik sebagai pilot project dari penerbit Pearson selama satu tahun dengan jumlah 1000 judul. Penawaran tersebut ditindaklanjuti oleh fakultas dengan melanggan buku teks elektronik sebanyak 500 judul untuk satu semester. Buku teks elektronik dapat diakses dengan menggunakan platform VitalSource. Sekolah kedokteran gigi di Universitas Losiana, Amerika sudah mengakses buku teks elektronik melalui platform VitalSource Bookshelf sejak tahun 2000. Kemudian baru tahun 2005, sekolah tersebut mewajibkan mahasiswanya untuk menggunakan dalam kegiatan belajar mengajar (Brunet et.al, 2011). Apabila buku teks elektronik dapat diintegrasikan dalam kegiatan pembelajaran, sering digunakan dengan istilah Learning Management Systems (LMS) maka akan membantu mahasiswa dalam mengembangkan pengalaman dan prestasi belajar mereka (Choi dan Lam, 2018).

LMS memberikan kesempatan dosen untuk menggunakan penilaian terintegrasi, alat pengumpulan data dengan statistik penggunaan yang lebih detail, serta fitur jejaring sosial yang memungkinkan dosen dan mahasiswa mudah untuk interaksi dalam berbagai materi pembelajaran (Bossaller dan Kammer, 2014). Saat ini, untuk melengkapi gaya hidup mahasiswa dalam 
memanfaatkan peralatan digital, menyediakan buku teks elektronik diyakini dapat menjadi pilihan yang lebih menarik dan memberikan pengalaman belajar yang fleksibel daripada menyediakan buku teks cetak (Novak, Daday, \& McDaniel, 2018).

Perpustakaan telah melakukan berbagai upaya agar buku teks elektronik dapat dimanfaatkan secara optimal. Perpustakaan mengirim email kepada seluruh sivitas akademika FEB UGM yang berisi informasi daftar judul buku yang dilanggan dan cara untuk mengaksesnya. Disamping itu, penerbit juga memberikan pelatihan cara pemanfaatan buku teks elektronik untuk administrator, dosen dan staf, serta mahasiswa.

Meskipun perpustakaan baru melanggan buku teks elektronik selama satu semester perlu dilakukan survei untuk mengetahui pemanfaatannya. Besarnya harga langganan dan berbagai upaya perpustakaan untuk mempromosikan keberadaan buku teks elektronik perlu dievaluasi sebagai dasar untuk memperpanjang langganan.

Berkaitan dengan hal tersebut maka, peneliti tertarik melakukan penelitian tentang pemanfaatan buku teks elektronik oleh mahasiswa FEB UGM. Peminjam buku teks elektronik masih terbatas untuk mahasiswa FEB UGM karena jumlah akun user masih berjumlah 3000, sehingga baru dapat memenuhi kebutuhan sivitas akademika di lingkungan FEB UGM. Disamping itu, untuk mengetahui upaya-upaya yang perlu dilakukan oleh perpustakaan untuk meningkatkan pemanfaatan buku teks elektronik. Brunet et.al, (2011) menyebutkan bahwa buku teks elektronik dapat diakses melalui platform VitalSource Bookshelf sejak tahun 2000.

\section{METODE PENELITIAN}

Penelitian ini menggunakan metode deskriptif yang bertujuan membuat deskripsi secara sistematis, faktual, dan akurat tentang fakta-fakta dan sifat-sifat populasi atau objek tertentu (Kriyantono, 2016). Jenis penelitian yang digunakan adalah kuantitatif. Menurut Soewadji (2012), jenis penelitian kuantitatif menekankan pengujian teori melalui pengukuran variabel penelitian dengan angka dan melakukan analisis dan dengan prosedur statistik.

Pengambilan data sampel diambil dari populasi dengan teknik purposive sampling yaitu memilih sampel dengan kriteria tertentu. Populasi dalam penelitian adalah mahasiswa Program studi S1 Fakultas Ekonomika dan Bisnis UGM yang berkunjung ke perpustakaan. Kriteria sampel adalah mahasiswa S1 dari semua prodi yang sudah pernah menggunakan buku teks elektronik dan masih berstatus aktif sebagai mahasiswa. Jumlah mahasiswa yang melakukan registrasi penggunaan buku teks elektronik sebanyak 2.270 orang. Untuk menentukan jumlah sampel menggunakan rumus Slovin (Soewadji, 2012), sehingga diperoleh jumlah sampel sebanyak 100 orang. Rumus Slovin digunakan untuk penelitian yang bertujuan untuk menghitung persentase.

Teknik pengumpulan data menggunakan kuesioner, observasi, dan wawancara terstruktur. Instrumen penelitian berupa angket tertutup dan panduan wawancara terstruktur. yang mengharuskan responden menentukan derajat persetujuan atau ketidak setujuan pada serangkaian pernyataan (Malhotra, 2009). Bentuk pertanyaan tertutup dengan alternatif pilihan jawaban untuk mengetahui karakteristik responden. Kemudian bentuk pernyataan untuk mengetahui sikap responden dalam memanfaatkan buku teks elektronik dengan cara memilih "Ya" atau "Tidak"

Analisis data dilakukan dengan mengelompokkan data berdasarkan variabel dan jenis responden, mentabulasi data, menyajikan data setiap variabel, melakukan perhitungan untuk menjawab rumusan masalah, dan melakukan pengujian hipotesis. (Sugiyono, 2013). Namun demikian dalam penelitian ini peneliti tidak melakukan uji hipotesis karena penelitian ini tidak menguji signifikansi variabel. Olah data menggunakan SPSS versi 20, kemudian dianalisis secara deskriptif. 


\section{HASIL PENELITIAN DAN PEMBAHASAN}

\section{Analisa Data Deskriptif Data Responden}

Pemilihan responden dalam penelitian ini menggunakan purposive sampling (sampel bertujuan). Kriteria responden dalam penelitian adalah mahasiswa S1, S2, dan S3 Fakultas Ekonomika dan Bisnis UGM, angkatan 2014, 2015, 2016, 2017, dan 2018, berstatus aktif, dan telah mendaftar sebagai pengguna buku teks elektronik. Jumlah sampel sebanyak 100 mahasiswa.

Berikut hasil analisis deskriptif identitas responden berdasarkan jenis kelamin ditunjukkan pada gambar 1.

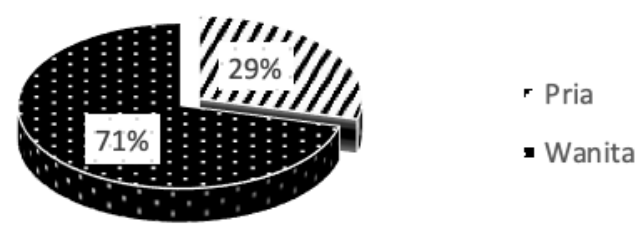

Gambar 1

Diagram Identitas Responden Berdasarkan Jenis Kelamin

Berdasarkan gambar 1 menunjukkan persentase responden berdasarkan jenis kelamin. Responden berjenis kelamin wanita berjumlah 29 orang (29\%), sedangkan responden berjenis kelamin pria berjumlah 71 orang $(71 \%)$.

Kemudian identitas responden berdasarkan angkatannya ditunjukkan pada gambar 2.

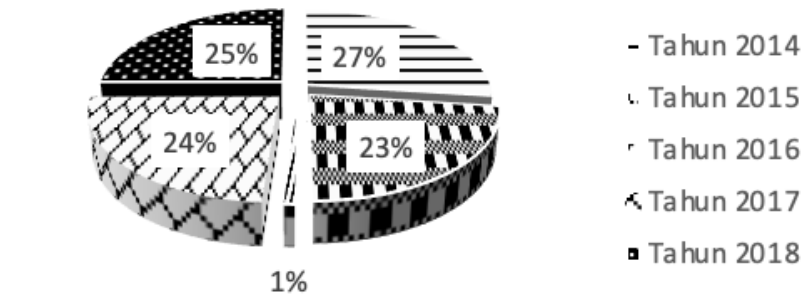

Gambar 2

Diagram Identitas Responden Berdasarkan Angkatan

Gambar 2 menunjukkan bahwa persentase responden berdasarkan angkatan. Responden angkatan tahun 2014 sebanyak 27 orang (27\%). Kemudian tahun 2015 sebanyak 23 orang (23\%), tahun 2016 sebanyak 1 orang (1\%), tahun 2017 sebanyak 24 orang (24\%), dan tahun 2018 sebanyak 25 orang $(25 \%)$.

Kemudian identitas responden berdasarkan departemen ditunjukkan pada gambar 3 .

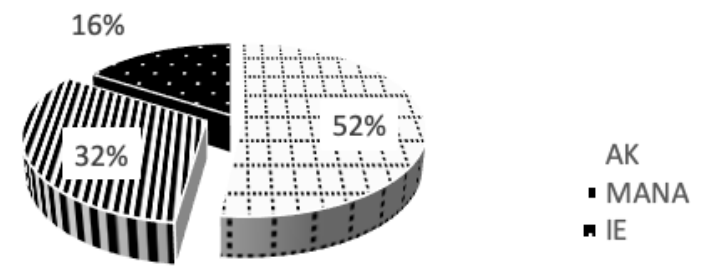

Gambar 3

Diagram Identitas Responden Berdasarkan Departemen 
Gambar 3 menunjukkan bahwa persentase responden berdasarkan asal departemennya. Responden dari Departemen Akuntansi sebanyak 52 orang (52\%). Kemudian responden berasal dari Departemen Manajemen sebanyak 32 orang (32\%), dan dari Departemen Ilmu Ekonomi sebanyak 16 orang $(16 \%)$.

Kemudian identitas responden berdasarkan program studi ditunjukkan pada gambar 4 .

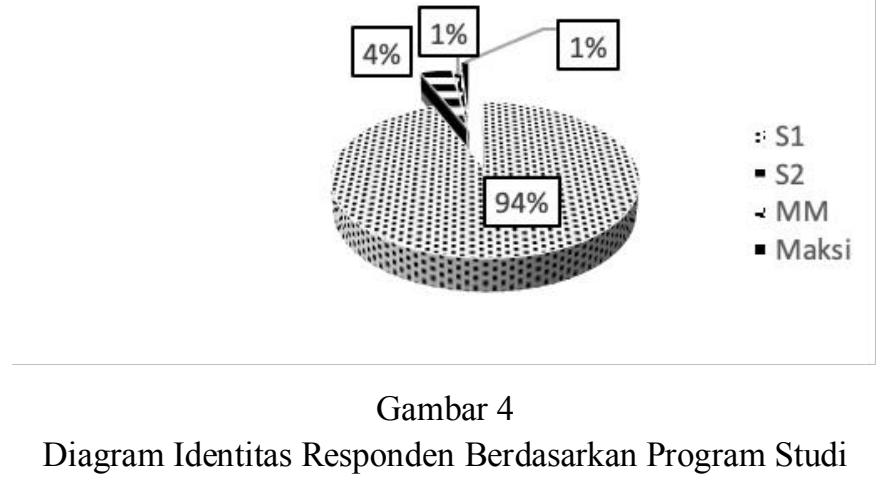

Gambar 4 menunjukkan persentase responden berdasar asal program studi. Responden yang berasal dari program studi Strata satu sebanyak 94 orang (94\%). Kemudian Strata dua sebanyak 6 orang, yang terdiri dari program studi S2 Reguler sebanyak 4 orang (4\%), program studi MM sebanyak 1 orang (1\%), dan Maksi sebanyak 1 orang (1\%).

Fakultas Ekonomika dan Bisnis Universitas Gadjah Mada mulai melanggan buku teks elektronik mulai ajaran semester ganjil 2018/2019. Pada saat itu, fakultas memperoleh panawaran langganan dari penerbit Pearson berupa pilot project untuk digunakan di perguruan tinggi yang ada di Indonesia. Beberapa judul buku dari penerbit Pearson digunakan sebagai buku teks wajib mata kuliah di tiga departemen. Namun yang paling banyak menggunakan buku teks tersebut adalah Departemen Akuntansi. Jumlah mahasiswa dari departemen akuntansi merupakan jumlah terbanyak apabila dibandingkan dengan departemen manajemen maupun Departemen Ilmu Ekonomi. Apabila melihat jumlah sampel dalam penelitian ini, jumlah sampel terbesar merupakan mahasiswa Departemen Akuntansi yaitu 52\%.

\section{Statistik Deskriptif Jawaban Responden}

Peneliti mengembangkan pertanyaan survei yang dilakukan oleh Kouis dan Konstantinou (2014) tentang pemanfaatan buku teks elektronik. Terdapat 11 deskripsi jawaban responden selama menggunakan buku teks elektronik yang telah dilanggan oleh fakultas. Persentase jawaban dapat dilihat pada tabel 1.

Tabel 1 menunjukkan persentase jawaban responden dari hasil analisis data SPSS pada setiap penyataan yang berkaitan dengan pemanfaatan buku teks elektronik. Secara lebih rinci jawaban responden untuk setiap pernyataan sebagai berikut:

\section{Penggunaan Buku Teks Elektronik}

Responden yang menyatakan pernah menggunakan buku teks elektronik yang dilanggan fakultas sebanyak 63 orang (63\%), sedangkan yang belum pernah menggunakan sebanyak 37 orang (37\%). Jadi buku teks elektronik yang dilanggan oleh fakultas sudah banyak digunakan oleh responden. 
Tabel 1

Persentase Jawaban Responden dalam Pemanfaatan Buku Teks Elektronik.

\begin{tabular}{|c|c|c|c|}
\hline \multirow[b]{2}{*}{ No } & \multirow[b]{2}{*}{$\begin{array}{c}\text { Pernyataan } \\
\end{array}$} & \multicolumn{2}{|c|}{ Persentase (\%) } \\
\hline & & Ya & Tidak \\
\hline 1 & $\begin{array}{l}\text { Saya pernah menggunakan buku teks elektronik yang } \\
\text { dilanggan fakultas }\end{array}$ & 63 & 37 \\
\hline 2 & $\begin{array}{l}\text { Saya menggunakan buku teks elektronik untuk kegiatan } \\
\text { perkuliahan }\end{array}$ & 76 & 24 \\
\hline 3 & $\begin{array}{l}\text { Saya menggunakan buku teks elektronik karena saran dari } \\
\text { dosen }\end{array}$ & 41 & 59 \\
\hline 4 & Saya menggunakan buku teks elektronik melalui laptop & 83 & 17 \\
\hline 5 & $\begin{array}{l}\text { Saya sudah tahu cara membuat highlight, membuat catatan, } \\
\text { dan membagikannya ke teman }\end{array}$ & 51 & 49 \\
\hline 6 & $\begin{array}{l}\text { Saya memerlukan pelatihan untuk menggunakan fitur buku } \\
\text { teks elektronik yang telah dilanggan }\end{array}$ & 64 & 36 \\
\hline 7 & $\begin{array}{l}\text { Saya merasa lebih mudah menggunakan buku teks } \\
\text { elektronik dibanding buku teks cetak }\end{array}$ & 49 & 51 \\
\hline 8 & $\begin{array}{l}\text { Saya merasa lebih nyaman menggunakan buku teks } \\
\text { elektronik dibanding buku teks cetak }\end{array}$ & 27 & 73 \\
\hline 9 & $\begin{array}{l}\text { Secara keseluruhan menggunakan buku teks elektronik } \\
\text { merupakan pengalaman yang positif bagi saya }\end{array}$ & 96 & 4 \\
\hline 10 & $\begin{array}{l}\text { Saya setuju apabila fakultas memperpanjang langganan } \\
\text { buku teks elektronik }\end{array}$ & 97 & 3 \\
\hline
\end{tabular}

Proses langganan buku teks elektronik dimulai pada awal semester ganjil tahun ajaran 2018/2019. Perpustakaan dan bagian pengadaan di fakultas berusaha agar buku teks elektronik segera dapat diakses oleh sivitas akademika. Ternyata pemilihan judul, persiapan koneksi dengan jaringan komputer fakultas, serta persiapan kontrak memerlukan waktu yang agak lama sehingga buku teks elektronik baru dapat diakses pada saat kegiatan perkuliahan sudah berlangsung empat minggu. Mahasiswa sudah mendapat buku acuan cetaknya yang diperoleh dari meminjam ke perpustakaan dan ada sebagian mahasiswa yang fotokopi.

Beberapa responden yang sudah mendaftar untuk dapat akses ternyata tidak menggunakan buku teks dari penerbit Pearson sebagai buku teks wajib mata kuliah, sehingga mereka tidak jadi mengakses buku yang telah dilanggan. Hal tersebut yang menyebabkan hanya 63\% mahasiswa mengakses buku teks yang dilanggan.

Pengadaan buku teks elektronik merupakan bentuk respon fakultas dalam memberikan fasilitas sumber belajar mengajar bagi sivitas akademika FEB yang sebagian besar merupakan generasi milenial. Perkembangan teknologi dan informasi yang berdampak pada perubahan format sumber informasi dari bentuk cetak menjadi bentuk digital maupun elektronik menjadi kebutuhan fakultas untuk melanggan buku teks elektronik. Apabila dilihat dari respon mahasiswa yang sudah menggunakan buku teks elektronik yang dilanggan masih $63 \%$ menunjukkan bahwa ketepatan waktu dalam pelaksanaan pengadaan buku sangat penting untuk diperhatikan. Buku teks elektronik seharusnya sudah siap untuk diakses ketika perkuliahan ajaran baru akan dimulai, sehingga intensitas pemakaiannya dapat optimal. Pengadaan buku teks elektronik lebih menguntungkan daripada pengadaan buku teks cetak. Buku teks cetak berbahasa Inggris pengadaannya lebih lama apabila buku tidak tersedia di distributor. Lama waktu pemesanan sampai dengan buku dikirim kurang lebih 3-4 bulan. Kadangkala buku baru sampai ke perpustakaan ketika kegiatan perkuliahan tinggal dua minggu. 


\section{Penggunaan Buku Teks Elektronik untuk Kegiatan Perkuliahan}

Responden yang memberikan pernyataan bahwa menggunakan buku teks elektronik untuk kegiatan perkuliahan sebanyak 76 orang (76\%), sedangkan tidak menggunakan buku teks elektronik untuk kegiatan perkuliahan sebanyak 24 orang (24\%). Jawaban responden sesuai dengan fungsi buku teks sebagai buku wajib dalam mendukung kegiatan perkuliahan.

Buku yang dilanggan dari penerbit Pearson merupakan buku teks elektronik untuk membantu ketersediaan buku teks yang digunakan dalam kegiatan perkuliahan. Diharapkan semua responden yang mengambil mata kuliah dengan menggunakan buku teks dari penerbit Pearson dapat membaca buku dengan mudah tanpa harus memfotokopi.

Namun demikian, beberapa responden ada yang mengakses buku teks elektronik tidak secata langsung digunakan dalam kegiatan pembelajaran, tetapi sebagai bacaan dalam penyusunan karya akhir. Ketersediaan buku teks elektronik dapat membantu mempermudah dalam mencari buku referensi.

Buku teks dengan bidang subjek sosio humaniora, termasuk bidang ekonomi lebih cepat perkembangannya apabila dibandingkan dengan bidang ilmu eksakta. Hampir setiap dua tahun sekali sudah terbit edisi baru. Jenis buku teks memang banyak digunakan untuk kegiatan perkuliahan, khususnya sebagai buku wajib mata kuliah yang harus dibaca oleh setiap mahasiswa. Ketersediaan silabus untuk setiap mata kuliah sangat penting bagi mahasiswa. Silabus memuat rencana kegiatan belajar mengajar selama satu semester. Biasanya meliputi standar kompetensi yang harus dicapai oleh mahasiswa, materi pokok setiap pertemuan, cara penilaian untuk mengukur keberhasilan belajar mahasiswa, dan sumber belajar yang digunakan dalam proses belajar mengajar.

Setelah satu semester fakultas melanggan buku teks elektronik, 63\% mahasiswa sudah menggunakannya. Buku teks elektronik dilanggan dengan maksud untuk memenuhi kebutuhan jumlah buku wajib yang diperlukan mahasiswa. Sebelum fakultas melanggankan buku teks elektronik, perpustakaan hanya dapat menyediakan buku teks yang dapat dipinjam dengan jumlah yang sangat terbatas. Sesuai fungsinya buku teks biasanya digunakan sebagai sumber informasi utama untuk kegiatan belajar mengajar. Oleh karena itu, sebanyak $76 \%$ responden mengunakannya untuk kuliah.

\section{Penggunaan Buku Teks Elektronik Karena Saran dari Dosen}

Responden yang menyatakan menggunakan buku teks elektronik karena saran dari dosen sebanyak 41 orang (41\%), sedangkan yang menyatakan menggunakan buku teks elektronik bukan karena saran dari dosen sebanyak 59 orang (59\%). Tidak semua dosen di FEB UGM menggunakan buku teks dari penerbit Pearson sebagai buku teks utama.

Buku teks elektronik yang baru dapat diakses setelah kegiatan kuliah sudah berlangsung empat minggu mempengaruhi Bapak/Ibu dosen untuk merekomendasikan pemanfaatan buku teks elektronik kepada semua responden. Bapak/Ibu dosen yang menggunakan buku teks dari penerbit Pearson saja yang akan merekomendasikan ke responden untuk mengaksesnya. Fasilitas yang diberikan fakultas bagi Bapak/Ibu dosen untuk dibelikan buku teks wajib dalam format cetak menyebabkan tidak segera mengakses format elektroniknya. Saran dari sesama teman responden dan informasi yang dikirim oleh perpustakaan yang menyebabkan responden melakukan akses buku teks lektronik.

Perpustakaan mempunyai kepentingan dengan ketersediaan silabus setiap mata kuliah. Terutama berkaitan dengan sumber belajar yang harus disediakan oleh perpustakaan. Sumber belajar dapat berupa bahan rujukan yang digunakan dalam kegiatan belajar mengajar seperti, 
koleksi buku, majalah, jurnal, atau jenis koleksi lainnya dalam format tercetak maupun elektronik. Ketersediaan silabus master di setiap program studi sangat membantu perpustakaan dalam menyiapkan bahan bacaan yang akan digunakan untuk kegiatan belajar mengajar. Perpustakaan akan selalu melakukan update bahan bacaan apabila sudah terbit edisi baru. Bahan bacaan yang tercantum di silabus akan dipilah-pilah berdasarkan penerbit. Bahan bacaan berupa buku teks dari penerbit Pearson akan dikirimkan ke penerbit untuk dilakukan pengecekan ketersediaan buku teks elektroniknya, sekaligus akan dilakukan up dating apabila sudah tersedia edisi barunya.

\section{Penggunaan Buku Teks Elektronik Melalui Laptop}

Responden yang menyatakan menggunakan buku teks elektronik melalui laptop sebanyak 83 orang (83\%), sedangkan yang menggunakan buku teks elektronik bukan melalui laptop sebanyak 17 orang $(17 \%)$. Saat ini, sebagian besar responden sudah mempunyai laptop sehingga responden mengakses buku teks elektronik dengan laptopnya sendiri.

Buku teks elektronik dengan platform VitalSource dapat diakses secara online maupun offline. Peralatan untuk mengakses dapat melalui komputer, laptop maupun smartphone. Bagi responden yang akan mengakses secara offline harus melakukan instal aplikasi terlebih dahulu. Kemudian melakukan proses peminjaman secara online. Setelah buku terpinjam, akses dapat dilakukan tanpa jaringan internet atau Wifi.

Sebagian besar responden mengakses dengan menggunakan laptop karena laptop menyediakan layar yang lebih lebar dari pada smartphone. Mereka menganggap bahwa membaca teks yang panjang akan lebih nyaman ketika menggunakan laptop. Disamping itu, saat ini hampir semua mahasiswa mempunyai laptop karena fasilitas Wifi sudah tersedia di beberapa tempat.

\section{Cara Membuat Highlight, Membuat Catatan, dan Cara Membagikannya}

Responden yang menyatakan sudah tahu cara membuat highlight, membuat catatan, dan membagikan ke teman sebanyak 51 orang (51\%), sedangkan yang belum tahu cara membuat cara membuat highlight, membuat catatan, dan membagikan ke teman sebanyak 49 orang (49\%). Platform VitalSource dilengkapi dengan beberapa fitur yang menarik untuk digunakan.

Aplikasi buku teks elektronik mempunyai beberapa fitur untuk memudahkan mahasiswa dalam membuat highlight, membuat catatan, dan fasilitas membagikan catatan-catatan yang sudah dibuat ke teman-temannya. Responden lebih mudah mencari kembali catatan-catatan yang telah dibuat dengan berbagai pilihan warna. Hal tersebut didukung penelitian dari Gueval, Tarnow, \& Kumm (2015) yang mengidentifikasi keuntungan buku elektronik yang diperoleh dari responden mahasiswa keperawatan di Kansas, Amerika yaitu fasilitas highlighting, searching, accessible, convenient, lighter load, on-line resource, dan download on more than one device.

Penerbit Pearson memberikan pelatihan tata cara mengakses buku teks elektronik beserta cara menggunakan fitur yang tersedia. Namun, karena responden yang dapat mengikuti pelatihan hanya sedikit menyebabkan pemanfaatannya belum optimal. Permasalahan untuk melibatkan banyak responden dalam pelatihan sangat sulit karena padatnya jadwal kuliah dan banyaknya kegiatan kemahasiswaan. Disamping itu, responden juga sudah merasa mempunyai buku teks untuk kegiatan perkuliahan dari meminjam di perpustakaan atau memfotokopi.

\section{Kebutuhan Pelatihan Menggunakan Fitur Buku Teks Elektronik}

Responden yang menyatakan memerlukan pelatihan untuk menggunakan fitur buku teks elektronik yang telah dilanggan sebanyak 64 orang (64\%), sedangkan yang menyatakan tidak memerlukan pelatihan untuk menggunakan fitur buku teks elektronik sebanyak 36 orang (36\%). Sebagian besar responden menyatakan masih memerlukan pelatihan dalam mengakses buku teks elektronik. 
Penerbit Pearson hanya memberikan pelatihan sekali selama fakultas melanggan buku teks elektronik. Responden dapat membaca guide tata cara menggunakan fitur yang ada di aplikasi. Namun demikian, untuk memperjelas penggunaannya perlu ditambah video tutorial agar dapat dimanfatkan lebih optimal. Menurut Cummings (2015), perpustakaan membutuhkan berbagai upaya untuk meyakinkan mahasiswa agar paham dan memberikan bimbingan cara untuk mengaksesnya.

Bentuk komitmen dari penerbit Pearson dalam mendukung FEB UGM dalam mengembangan pembelajaran digital serta meningkatkan efisiensi penggunaan buku teks elektronik maka, pihak Pearson akan memberikan pelatihan secara berkala kepada dosen maupun responden. Pihak penerbit juga bersedia menempatkan salah satu stafnya satu minggu sekali untuk membantu apabila ada permasalahan terkait dengan pemanfaatan buku teks elektronik. Pelatihan pemanfaatan buku teks elektronik untuk responden masih sangat diperlukan. Hal tersebut didukung pernyataan responden, sebanyak $64 \%$ menyatakan masih memerlukan pelatihan. Responden yang sudah tahu cara membuat highlight, membuat catatan, dan membagikannya ke temannya hanya $51 \%$. Menentukan alokasi waktu yang tepat untuk menyelenggarakan pelatihan dan model pelatihan yang menarik minat responden untuk mengikuti menjadi hal yang penting pada saat membuat perencanaan kegiatan. Disamping itu, Bapak/Ibu dosen mempunyai peran untuk membantu mensosialisasikan pemanfaatannya kepada responden, sehingga langganan buku teks elektronik menjadi kebutuhan untuk mendukung kesuksesan kegiatan belajar mengajar. Menurut pendapat responden, mereka menjawab bahwa menggunakan buku teks elektronik karena saran dari dosen sebesar $41 \%$.

\section{Kemudahan Menggunakan Buku Teks Elektronik Dibanding Buku Teks Cetak}

Responden yang menyatakan merasa lebih mudah menggunakan buku teks elektronik dibanding buku teks cetak sebanyak 49 orang (49\%), sedangkan yang merasa tidak lebih mudah sebanyak 51 orang $(51 \%)$. Sebagian besar responden menyatakan bahwa menggunakan buku teks cetak lebih mudah daripada buku teks elektronik.

Aplikasi yang digunakan untuk mengakses buku teks elektronik memerlukan dua tahap sampai responden dapat mengakses buku teks yang dilanggan. Tahap pertama responden harus melakukan registrasi secara mandiri. Registrasi harus menggunakan email UGM, yang menunjukkan bahwa responden memang berasal dari UGM. Tahap kedua admin fakultas melakukan input responden yang telah melakukan registrasi ke aplikasi VitalSource. Dalam waktu 1 kali 24 jam respondenbaru dapat melakukan create account ke aplikasi. Password untuk mengakses buku teks elektronik menggunakan kombinasi huruf besar dan karakter unik. Hal tersebut yang kadang menjadi permasalahan responden melakukan create account. Mereka kurang memperhatikan ketentuan yang diberikan oleh aplikasi.

Lain halnya, ketika mereka meminjam buku cetak di perpustakaan. Mereka cukup mencari katalog buku dari komputer yang telah disediakan, kemudian mencari di rak sesuai kode buku. Apabila responden sudah sering meminjam buku maka akan lebih mudah untuk mendapatkan di rak. Mereka akan merasa lebih mudah menggunakan buku cetak dari pada menggunakan buku teks elektronik yang harus melakukan beberapa tahapan untuk dapat membacanya. Membaca buku cetak masih disukai sebagian orang. Hal tersebut didukung hasil survei Zhang \& Kudva (2014) bahwa dari 2.986 responden di Amerika menyatakan e-book telah menjadi bagian dari kehidupan masyarakat dengan adanya kemudahan akses, namun e-book belum memiliki masingmasing keunikan yang tidak dapat saling menggantikan dalam memenuhi kebutuhan membaca masyarakat. Orang-orang sangat suka membaca buku cetak ketika mereka membaca bersama 
anak-anak mereka. Selain itu, buku cetak juga masih disukai untuk membagikannya dengan orang lain. Lebih jelas bahwa e-book dan buku cetak mempunyai fungsi yang unik dalam situasi yang berbeda. Namun demikian, semakin berkembangnya teknologi buku elektronik akan semakin banyak diminati karena dapat diakses melalui smart phone serta adanya kemudahan dalam penelusuran informasi (Li, 2016).

\section{Kenyamanan Menggunakan Buku Teks Elektronik Dibanding Buku Teks Cetak.}

Responden yang menyatakan merasa lebih nyaman menggunakan buku teks elektronik dibanding buku teks cetak sebanyak 27 orang (27\%), sedangkan yang menyatakan tidak merasa lebih nyaman sebesar 73 orang (73\%). Sebagian besar responden menyatakan bahwa buku teks cetak lebih nyaman ketika digunakan dalam kegiatan perkuliahan.

Penerbit Pearson mengembangkan layanannya sesuai perkembangan teknologi informasi dan komunikasi. Saat ini, sebagian besar responden merupakan generasi milenial yang sudah terbiasa dengan pemanfaatan teknologi informasi. Berbagai keuntungan dan kekurangan buku teks elektronik sudah dijelaskan di bagian tinjauan pustaka dan beberapa penelitian terdahulu.

Kebiasaan membaca dengan teks yang panjang masih nyaman apabila membaca melalui buku cetak. Pengaruh cahaya dari komputer, laptop maupun smartphone ketika membaca buku teks elektronik akan mempengaruhi kemampuan mata untuk dapat bertahan membaca. Pada umumnya mereka akan merasa lebih cepat lelah membaca dari layar monitor dari pada membaca dari buku cetak. Hasil survei jelas menunjukkan bahwa 73 orang responden kurang nyaman membaca buku teks dari layar monitor. Hal tersebut didukung hasil penelitian dari Ji, Michaels, \& Waterman (2014) bahwa penggunaan buku wajib yang diakses secara elektronik, hampir setengah dari total halaman dibaca secara online tetapi sebagian besar responden menyatakan bahwa ketika versi cetak disediakan maka mereka akan lebih banyak membaca untuk belajar.

Kemudahan akses merupakan salah satu unsur yang penting untuk memperoleh sumber informasi yang sesuai dengan kebutuhan responden. Aplikasi yang disiapkan oleh VitalSource memudahkan mahasiswa untuk mengakses buku teks elektronik pada 4 gawai pribadi masingmasing, baik secara online maupun offline. Sebagian besar responden mengakses buku teks elektronik menggunakan laptop yaitu, mencapai $83 \%$. Bentuk layar yang lebih lebar, hampir sama ukurannya dengan buku cetak sehingga responden masih merasa nyaman ketika membacanya. Apabila diakses dengan menggunakan smartphone, responden masih kurang nyaman karena layarnya lebih kecil yang dapat membuat mata mudah lelah pada saat membacanya. Alasan lain, keterbatasan ruang penyimpanan pada smartphone menjadikan alasan responden mengakses buku teks elektronik dengan laptop yang mereka miliki. Hal tersebut hanya didukung pendapat responden sebanyak $27 \%$ yang menyatakan bahwa menggunakan buku teks elektronik lebih nyaman dari pada buku cetak.

\section{Pengalaman Positif Menggunakan Buku Teks Elektronik}

Responden yang menyatakan bahwa secara keseluruhan menggunakan buku teks elektronik merupakan pengalaman yang positif sebanyak 96 orang (96\%), sedangkan yang menyatakan bahwa secara keseluruhan menggunakan buku teks elektronik merupakan pengalaman yang kurang positif sebanyak 4 orang (4\%). Sebagian besar responden menyatakan bahwa menggunakan buku teks elektronik merupakan pengalaman yang positif.

Perkembangan teknologi yang menyediakan pemanfaatan buku teks elektronik dengan berbagai kelebihannya dapat memberikan pengalaman baru atau pengalaman positif dari sebagain besar responden. Beberapa fitur yang tersedia lebih menarik minat untuk digunakan. Kecepatan menemukan kembali informasi yang dianggap penting dan dapat membagi dengan temannya juga menjadi kelebihan dari buku teks elektronik. Kehadiran buku teks elektronik menjadikan suasana 
kegiatan belajar mengajar menjadi lebih berbeda dibanding dengan sistem konvensional. Menurut Pinto, Pouliot, \& Cordon-Garcia (2014) dalam penelitiannya meminta responden untuk membandingkan keuntungan buku cetak dan e-book. Mereka menganggap bahwa keuntungan terbesar $e$-book adalah berkaitan dengan masalah lingkungan, selain mudah penyimpanannya dan kemudahan untuk dibagikan serta harga yang lebih murah.

\section{Perlunya Memperpanjang Langganan Buku Teks Elektronik}

Responden yang menyatakan setuju apabila fakultas memperpanjang langganan buku teks elektronik sebanyak 97 orang (97\%), sedangkan yang kurang setuju apabila fakultas memperpanjang langganan buku teks elektronik sebanyak 3 orang (3\%). Sebgian besar responden setuju apabila buku teks elektronik untuk tetap dilanggan.

Pengalaman positif dengan dilangganannya buku teks elektronik membuat sebagian besar responden setuju apabila fakultas memperpanjang langganan buku teks elektronik. Kebutuhan penggunaan teknologi untuk meningkatkan efektifitas belajar, khususnya di perguruan tinggi sudah menjadi fokus pengembangan di beberapa perguruan tinggi. Melanggan buku teks elektronik merupakan salah satu upaya pengelola fakultas untuk meningkatkan efektifitas belajar mengajar. Selain itu, bertujuan untuk menyediakan materi sumber belajar kepada seluruh responden, menyediakan sumber belajar yang terpercaya, serta menyediakan sumber belajar dengan harga yang lebih terjangkau. Secara keseluruhan, 96 responden menyatakan bahwa pemanfaatan buku teks elektronik di FEB UGM merupakan pengalaman yang positif selama mengikuti proses pembelajaran dan setuju apabila langganan buku teks elektronik diperpanjang masa langganannya.

\section{SIMPULAN}

Pemanfaatan buku teks elektronik yang dilanggan oleh Fakultas Ekonomika dan Bisnis Universitas Gadjah Mada telah dimanfaatkan oleh mahasiswa meskipun belum optimal. Hal tersebut disebabkan karena penggunaan buku teks elektronik masih dalam masa transisi dari buku teks cetak yang tersedia di perpustakaan ke buku teks elektronik yang baru dilanggan satu semester.

Sebagian besar mahasiswa menggunakan buku teks elektronik untuk kuliah, mengakses melalui laptop, dan masih memerlukan pelatihan cara membuat catatan, highlight, dan membagikannya ke teman. Namun demikian, mahasiswa masih merasa lebih nyaman membaca buku teks cetak dari pada buku teks elektronik. Pemanfaatan buku teks elektronik bagi mahasiswa merupakan pengalaman positif dalam kegiatan belajar dan mereka setuju apabila buku teks elektronik untuk tetap dilanggan oleh fakultas.

Beberapa upaya yang perlu dilakukan oleh perpustakaan untuk meningkatkan pemanfaatan buku teks elektronik antara lain, memberikan layanan bimbingan cara pemanfaatan buku teks elektronik secara berkala, melakukan sosialisasi pemanfataan buku teks elektronik melalui media sosial yang di update secara berkala, memberikan reward mahasiswa yang aktif menggunakan buku teks elektronik, serta menobatkan salah satu mahasiswa berprestasi sebagai duta baca sumber materi elektronik.

\section{DAFTAR PUSTAKA}

Bossaller, J. \& Kammer, J. (2014). Faculty views on etextbooks: a narrative study. College Teaching, 62: 68-75. DOI 10.1080/87567555.2014.885877 
Brunet, D.P., Bates, M.L., Gallo, J.R., \& Strother, E.A. (2011). Incoming dental students' expectations and acceptance of an electronic textbook program. Journal of Dental Education, 75(5): 646-652.

Choi, P.M.S., \& Lam, S.S. (2018). A hierarchical model for developing e-textbook to transform teaching and learning. Interactive Technology and Smart Education, 15(2): 92-103. DOI 10.1108/ITSE-12-2017-0063

Cummings, L.A., Larrivee, A., \& Vega, L. (2015). Comparing electronic vs print book preferences between students in the sosial science, the arts and STEM. Library Hi Tech News, 32(4): 1-5. DOI 10.1108/LHTN-10-2014-0088.

Gueval, J., Tarnow, K., \& Kumm, S. (2015). Implementing e-books: Faculty and student experiences. Teaching and Learning in Nursing, 10: 181-185. DOI 10.1016/j.teln.2015.06.003

Ji, S.W., Michaels, S. \& Waterman, D. (2014). Print vs. Electronic readings in college course: Cost-effiency and perceived learning. Internet and Higher Education, 21: 17-24.

Kementerian Pendidikan Nasional Republik Indonesia. (2008). Peraturan Menteri Pendidikan Nasional Republik Indoensia Nomor 2 Tahun 2008 tentang buku. Jakarta: Departemen pendidikan Nasional.

Kouis \& Konstantinou (2014). Electronic textbooks advantages and challenges for the Hellenic higher education and publishing community. Library Review, 63 (6/7): p. 531-543. Diakses dari http://www.emeraldinsight.com

Kriyantono, R. (2006). Teknik praktis riset komunikasi. Jakarta: Kencana.

$\mathrm{Li}$, J. (2016). Is it cost-effective to purchase print books when the equivalent e-book is available? Journal of Hospital Librarianship, 16(1): 40-48. DOI 10.1080/15323269.2016.1118288

Malhotra, N.K. (2009). Riset pemasaran: Pendekatan terapan jilid 1. (Penerjemah Soleh Rusyadi Maryam). Jakarta: Indeks.

Muslich, M. (2016). Text book writing: Dasardasar pemahaman, penulisan, dan pemakaian buku teks. Jakarta: Ar-ruzz Media.

Novak, E., Daday, J., \& McDaniel, K. (2018). Assessing intrinsic and extraneous cognitive complexity of e-textbook learning. Interacting with Computers, 30 (2): 150-161.

Pinto, M., Pouliot, C.,\& Cordon-Garcia, J.A. (2014). E-book reading among Spanish University student. The Electronic Library, 32 (4): 473-492.DOI 10.1108/EL-05-2012-0048.

Prastowo, A. (2015). Panduan kreatif membuat bahan ajar inovatif. Yogyakarta: DIVA Press.

Rao, K.N., \& Kumar, S. (2018). E-book and print book rice and desirability for university libraries: a comparative study. The Electronic Library, 36 (1): 82-102. DOI 10.1108/EL-062016-0142

Rockinson-Szapkiw, A.J., Courduff, J., Carter, K., \& Bennett, D. (2013). Electronic versus traditional print textbooks: A comparison study on the influence of university students' learning. Computers \& Education, 63: 259-266.

Soewadji, J. (2012). Metodologi penelitian. Jakarta: Mitra Wacana Media.

Sugiyono (2013). Metode penelitian manajemen: Pendekatan kuantitatif, kualitatif, kombinasi, penelitian tindakan dan penelitian evaluasi. Bandung: Alfabeta.

Woody, D.W.', Daniel, D.B, \& Baker, C.A. (2010). E-books or textbooks: Students prefer textbooks. Computers \& Education, 55: p. 945-948. Diakses dari http://www.elsevier.com.

Zhang, Y. \& Kudva, S. (2014). E-books versus print books: Readers' choices and preferences across contexts. Journal of The Association for Information Science and Technology, 65(8): 1695-1706. 